\title{
The Development of Competitive Industries: The Role of State Government Actors
}

\section{Introduction.}

Since the 1970s, the onrush of globalisation in Australia's markets has presented significant economic policy challenges to the country's federal and state governments (Everett, 2002; Goldfinch, 1999). A major challenge for Australian legislators was (and remains) making a nation previously protected by a 'fortress' of tariffs and subsidies more productive and competitive in world markets (Brown, 2000; Edwards, 2002; Martin, 2000). One theoretical framework that achieved prominence in Australian economic policy development in the 1990s, largely due to its intuitive appeal and apparent value in increasing the competitive advantage of nations, is Porter's (1990) Industrial Cluster Theory (ICT) (Boddy, 2000). In The Competitive Advantage of Nations, Porter argued that for a modern economy to advance within a globalised marketplace, it needed to foster innovative industries able to compete successfully on an international scale. In order to best achieve this, Porter argued that governments needed to recognise and facilitate the growth of innovative industry 'clusters', particularly those enjoying some level of local advantage that could not be readily imitated elsewhere. In Australia, acceptance of this belief was expressed in the federal government's manufacturing reports, which introduced Porter's notion of industrial cluster development into government policy by proposing the development of regional industry partnerships that strengthened networks, encouraged innovation, and the inter-firm transfer of technology (Australian Manufacturing Council, 1994; Bureau of Industry Economics, 1991). 
In addition to this, in 1993, a federal government investigation into the requirements of a sustainable economic development strategy for the nation highlighted the need for Australia's regional economies to similarly optimise their economic productivity by developing their localised advantages (Keating, 1994; Kelty, 1993). This was followed by the McKinsey Report 'Lead Local, Compete Global' (McKinsey \& Company, 1994) which was the first report to suggest that ICT was an appropriate basis upon which to develop Australia's regional economies to internationally competitive standards. Given the level of investigation and documentation undertaken, it is apparent that successive Australian governments believed the conditions leading to the formation of internationally competitive 'wealth-generating' industry clusters (such as the internationally renown 'Silicon Valley' in the United States) could simply be replicated to help foster the inception and growth of new Australian industries, and to re-engineer older ones to world standards (Ivarsson, 1999).

Despite the widespread adoption of ICT as a policy framework by federal and state governments over the past decade, Australia has remained significantly below the OECD average in terms of its industries' economic contributions to real wealth creation (Brown, 2000; OECD, 1998; Porter, 2002, cited in James, 2002). Brown (2000) suggests Australia's poor performance is almost entirely predicated on the inability of its governments to fulfil their role within Porter's ICT framework. Brown's (2000:13) comment that Australian governments have displayed a "very confused role" in their industrial policy development was echoed by Porter in 2002, when he stated: “Australia does not have a strategy for competing in the global economy, and is not doing what is necessary to get one” 
(in James, 2002: 13). In terms of incorporating Porter's ICT as part of a definitive 'policy role for government', Porter himself notes that:

...in Australia, what is less understood is that the government has some positive roles, like innovation and training, infrastructure, and things like that. I think that the real frontier is [understanding] the positive roles to be played by government whilst avoiding the distortion or intervention in competition (in Trinca, 2002:39).

This paper reports upon an examination of key government policy initiatives associated with the development of an internationally competitive shipbuilding industry in the regional economy of Tasmania. As part of a larger study concerning innovation and economic development, this paper's focus on the Tasmanian state government's role in facilitating the innovative capacity of the Tasmanian Light Shipbuilding industry may prove useful to policy makers in other regional economies.

Industrial Policy Development and Australian Government Competency: A Review of the Literature.

The history of regional economic policy development in Australia is characterised by the use of fads (Doeringer \& Terkla, 1996, in Staber, Schaefer \& Sharma, 1996). In the 1960s, mature ‘smokestack' industries were the focus of industrial recruitment and retention policies. In the 1970s, the attention of policymakers turned to high-technology industries, and the 1980s saw the attraction of foreign direct investment become popular. Given that the economic advantages of industrial development were well established in the literature, it is not surprising that Porter's ICT was widely accepted by policymakers around the globe in efforts to improve both mainstream and regional economic performance (Feser \& Bergman, 2000). However, many examples of economic policy failure exist, whereby government efforts to create an ideal economic climate for 'industrial clustering' have either failed outright (e.g. the Adelaide Multi- 
function Polis), or have performed far below expectations (see Doeringer \& Terkla, 1996, in Staber, Schaefer \& Sharma, 1996).

Within the literature, the observed barriers to effective governmental implementation of Porter's ICT as an industry policy framework have been attributed to four main causes. The first has been that much of the policy development to date has largely been focused on information gathering rather than on achieving either business participation or greater understanding of the industrial clustering process (Davies, 2001). The second suggests that much of the policy development to date has largely been based on the attempted replification of 'industrial cluster policy successes' found elsewhere (Boddy, 2000). The third cause suggests that although governments may have the ability to effectively identify working and potential industries, there is an assumption by policymakers that the mere provision of scarce resources will, in of itself, ensure an industry's economic success. The fourth cause relates to the simultaneous (and potentially incongruent) governmental adoption of macro-economic rationalist policies.

The first major cause cited for government policy failure surrounds the observation that government policy development has largely been focused on descriptive information gathering rather than on achieving either business participation or greater understanding of the industrial clustering process (Davies, 2001). In many of the failed IC policy developments, researchers have noted that government policy appears to have been based upon a lack of clear understanding of local and interregional industrial linkages, and the channels of 
technology and knowledge transfer, which meant that relatively simple measures (such as location quotients and industry size) have often been used by government to detect potential growth industries in sub-national regions (Gordon \& McCann, 2000).

The second major cause sited suggests that much of the policy development to date has largely been based on the attempted replification of 'industrial cluster policy successes’ found elsewhere (Boddy, 2000). Of particular concern has been the reliance of government policymakers on a limited set of particularly successful technological industries such as Silicon Valley, Hong Kong's financial district, Boston’s Route 128, and Cambridge in the UK. Boddy (2000) suggests that there are clear dangers in simply attempting to reproduce significant policy direction from a relatively small number of specific cases, especially those whose economic success is atypical and often based on relationships that have developed over a considerable period within a particular industry.

The third cause discussed concerns the government's allocation of its scarce resources as a potential ineffective policy approach to industry formation. Feser and Bergman (2000) note that, at least at the local level, the approach frequently adopted by policymakers involves little more than the identification of current regional specialisations as targets for traditional development initiatives. In such cases, industry policy strategy serves more often as a means of allocating scarce resources than as a way to build the linkages and future inter-industry synergies documented so frequently in successful industrial districts (Feser \& Bergman, 
2000). For example, in Australia, many 'planned' industry policy frameworks have failed to materialise despite heavy investments by government into setting up the infrastructure required to support emergent industries (OECD, 1998).

The fourth cause has been the inadequacy of conventional approaches to governmental industry policy development in the face of the macroeconomic rationalism of the 1990s. Important though this effort is, the policy context has not always encouraged the analytical clarity which is required both for empirical testing of the theorised industrial cluster propositions, and for assessing the broad scale of benefits which the various kinds of policy initiative might be expected to yield in different contexts (Digiovanna, 1996). In addition, the nature of political will towards industrial cluster policy has also proven to be both highly changeable and problematic in the 1990s. Given the relatively short terms of government, and the rather longer time-frame required for emergent industries to become established in an economy, short-term political problems and policy shifts can have detrimental affects on planned industry initiatives. In Australia, for example, the economic recession of 1989-1993 resulted in a federal government policy shift away from funding state-based industrial policy projects, which resulted directly in the major alteration, and even abandonment of, many state-based industry policy initiatives in the late 1990s (see Boddy, 2000).

Due to the absence of agreed-upon criteria, and the relatively 'poor performance' of Australia industry policies by OECD standards, it has been argued that Australian policy development has been based on largely 'backward looking models' that provide little predictive value (Ellis \& Pecotich, 2002; Rajneesh, 
1993). Indeed, much of the literature on how Australian governments have constructed (or should construct) their industry policy fails to demonstrate their understanding of how to implement effective development policies. Instead, industrial policies appear to emerge from judgements based on broad industry growth forecasts, untested predictions regarding the business potential of particular technologies, and examples of idiosyncratic industry configurations that have been successful elsewhere (Doeringer \& Terkla, 1996, in Staber, Schaefer \& Sharma, 1996; Rugman, 1991; Yetton et al, 1992).

\section{The Case of the Tasmanian Light Shipbuilding Industry (TLSI).}

In order to understand the positive role that an Australian government can play in the development of internationally competitive industries, this paper undertakes an examination of the 25-year history of one of Australia's most successful export industries, that of the TLSI (Industry Audit, 1998). The value of the TLSI to the regional Tasmanian economy is beyond question. Since its inception in 1977, the TLSI has grown substantially in terms of both its sales volume and innovative output (Industry Audit, 1998). At its peak between 1996 and 1998, the TLSI generated an annual turnover of AUD\$400 million in export earnings for the Tasmanian economy (accounting for 23 percent of the state's merchandise export revenues), and employed approximately 2500 people (Industry Audit, 1998). The TLSI also boasts the world's leading manufacturer of high-speed aluminium ferries, International Catamarans, which at the peak of the industry's output, managed to capture 40 percent of the world's passenger ferry market, simultaneously earning the status of being the regional economy's largest private sector employer (Wickham \& Hanson, 2002). 
In 2005, the TLSI comprised eleven entities - International Catamarans (a producer of innovative fast-ferry catamarans, and the driving force behind the industry’s international success); Colbeck \& Gunton (maritime fire protection equipment); APCO Engineering (a 'cast and machined component' manufacturer); Liferaft Systems (a producer of maritime safety equipment); Riley Industrial \& Marine Sales (a marine hydraulics manufacturer); Richardson Devine Marine (a producer of aluminium pleasure-craft); Muir Engineering (winches and associated maritime machinery); FC Management (a mono-hull passenger ferry manufacturer); North West Bay Ships (a producer of a diverse range of aluminium passenger ferries); the Australian Maritime College; and the TAFE Aluminium Welding School (Industry Audit, 1998).

\section{Method.}

This research comprised a comprehensive series of semi-structured interviews with all of the key informants within the TLSI and the state government during the period 1977 to 2002. Interviews were conducted with each of Tasmania's state Premiers during the TLSI's formation, the managing directors of the TLSI firms, and the heads of government departments and agencies with which the TLSI had significant interactions. In total 25 semi-structured interviews were conducted, each lasting between 60 and 90 minutes. The interview questions posed to the participants were derived from an extensive collection and analysis of historical data pertaining to the TLSI's development. As such, the interviews contained both standardised interview questions (i.e. common to all informants) and specific interview questions (i.e. aimed at the key informants' specific involvement in the TLSI's history), and were formulated to elicit the primary data required to answer the research questions posed in this inquiry. Both the 
standardised and specific interview questions were formulated to facilitate the aggregation, analysis, triangulation, and validation of information, and enabled the researcher to interrogate the evidence gathered from other sources. These questions were designed to cover the necessary issues, but were framed in an open-ended manner, to allow the interviewees sufficient latitude for introspection and open reporting of their own perspectives. As a result, the informants were free to pursue those matters that they considered important.

This collection of primary data using a semi-structured interview method allowed the informants to tell their own story in their own way, thereby allowing the researcher direct access to the experience of the case (Clandinin \& Connelly, 1994). These individualised recollections aid to strengthen the inquiry by counteracting the bias that may exist in the secondary documents (Burgess, 1982), by adding matters of fact or detail that may only be recorded in individual memory (Samuel, 1982), and by giving voice to those not usually heard (Fontana \& Frey, 1994). The semi-structured interviews assisted this inquiry in each of these areas, as they enabled the researcher to access facets of the case that would not have been available by any other data gathering technique. The interpretation of the data, and the verification of the conclusions, were facilitated by the use of the QSR NUD*IST (version 6.0) software package. In the method literature, it has been emphasised that computer software programs such as NUD*IST, are of significant value in qualitative analysis and any subsequent theory building (Kelle, 1995; Richards \& Richards, 1995; Weitzman \& Miles, 1995). The interview transcripts were imported into the NUD*IST software database, following which the categories (i.e. the coding of the data) were 
established as a series of nodes. These nodes formed part of an index system that the software depicts as a 'stem and leaf' system of association.

One of the most prevalent concerns surrounding the reporting of longitudinal industrial development research concerns the evolutionary nature of the industrial life cycle. Peters and Hood (2000) discuss how the industrial life cycle notion can influence the effectiveness of a government's industry policy platform. A growing literature base suggests that 'who innovates' and 'how much' innovative activity is undertaken by an industry is closely linked to the phase of the industry life cycle, and is of vital importance to effective policy implementation (Klepper, 1996). It is therefore necessary for this research to highlight the longitudinal variation in government policy generation, and link them to the developmental needs of the TLSI over the stages of the TLSI's life cycle.

\section{Discussion.}

A reflection upon the Tasmanian government's policy initiatives during introductory stage of the TLSI's life cycle (1977-1984).

During the introductory stage of its life cycle, three key government roles were perceived to positively influence the TLSI's development. The first was the state government's initial non-committal stance towards the specific development of the state's 'new' shipbuilding industry. The second role surrounded the enhancement of the state's reputation within the domestic market as a centre for maritime research. The third role was the government's support for the entrepreneurial activities undertaken by Incat, when it became apparent that the company was a potential source of significant economic growth for the regional economy. 
The state government's initial non-committal stance towards the state's 'new' industry was not deliberate, as its policy focus at the time was on the macroeconomic restructuring of the state's economy away from its dependence on hydro-industrialisation:

At the end of the Reece era [the previous state Premier of] Tasmania had probably exploited the industries associated with hydro-industrialisation - not exploited but got the best out of it - and it was a bit of a turning point then...time to try something totally new (Doug Lowe. Personal Interview, 2002).

Due to this focus on the macro-economic restructuring process, the state government did not at any stage focus on, or pre-empt the growth requirements of the industry. The Premier of the day recalled that:

\begin{abstract}
We didn't perceive it as anything special. You have come one step further than the actual development of policy that lead to the establishment of the shipbuilding industry. The thrust of government industrial development policy in the mid 1970's was really evolving from a very bureaucratised public sector government structure advisory secretariat seated within government, predominantly from people who were experienced in the public sector as distinct from the commercial sector itself (Doug Lowe. Personal Interview, 2002).
\end{abstract}

As such, the Tasmanian government avoided the issues surrounding many of Australia's industry policy failures prevalent in the 1990s in which governments built up the infrastructural support to potential industries in the hope that this would attract firms, as for example, the federal and South Australian government did with the failed Multi-Function Polis planned for Adelaide. Consequently, the development of the innovative technologies remained the sole responsibility of the private sector firms that existed during the industry's initial formation (i.e. the managing director of Incat and his maritime friendship network). As stated by Premier Groom:

... if government takes a too bigger role in [the private sector's activities] that is fraught with huge dangers because the record of government running shows is not very good. I happen to believe government needs to be there backing up...but the innovative process is still fundamentally a private enterprise show (Ray Groom. Personal Interview, 2002). 
The second key role was the state government's development of the region's reputation within the broader domestic maritime market as a national centre for maritime research. The Tasmanian government implemented a series of lobbying initiatives that resulted in the federal government providing additional funding to the Australian Maritime College (a federally funded training facility based in Launceston) and relocating its national maritime research institute (the CSIRO) to Hobart. Premier Lowe said of this strategy that:

\begin{abstract}
The next step in my judgement was to make sure that we made Tasmania, as far as possible, a super centre for southern oceans activity and we looked specifically at developing ship servicing facilities, particularly in the Port of Hobart but also looking at the Tamar Valley in Launceston, it had developed of its own initiative a lift operation for smaller vessels, both for construction and for overhaul, so we had, at both ends of the state some great work going on (Doug Lowe. Personal Interview, 2002).
\end{abstract}

These state government efforts were largely aimed at the federal government rather than the private sector, but their success had implications for the region's infrastructure. The regional economy's infrastructures were advanced by developing the region's human capital through the generation of specialised employment and education within the broader industry. The regional economy's supporting industries were similarly developed by the increase in the sophistication of supply to the private sector firms (in terms of products and world standard maritime research). The Tasmanian government's enhancement of the region's reputation helped to develop the demand conditions faced by the private sector shipbuilding firms, most significantly by increasing customer willingness to import their products. In response to the exporting success of Incat's catamarans in the early 1980s, the Tasmanian government undertook its third key role, that of accommodating the growth requirements of Incat with a loan guarantee for its innovative aspirations. 
Although the Tasmanian government did provide its first direct support for Incat's innovative ship designs in the introductory stage of the TLSI's life cycle, it did so only after the company was able to demonstrate its commercial success in the domestic market for ferry transportation. The government support for Incat was provided when the firm could demonstrate that it did not possess the resources required for its continued expansion, and then only after its management was able to demonstrate that significant increases in employment were the likely result of the support. As the Premier of the day noted:

I think we saw [Incat] as one opportunity amongst many- but I don't think it was ever thought, "We could become a grand shipbuilding nation of the world?" Whatever. I think it was - "Let's see how if this one goes and we will get on with the next one then". We didn't have a dream that we were going to be building great shipbuilder's names. I think the first thing was to try and support the fact that it was a central business and flowing from that there would be other offshoots of success to develop (Robin Gray. Personal Interview, 2002).

This initial government support is consistent with the recommendation of Porter's ICT, as it allows for the challenges facing the 'new' industry to be overcome whilst avoiding the inefficiencies associated with the government's direct involvement in private sector enterprise. The introductory stage of the TLSI's life cycle was, therefore, characterised by the arm's length relationship between the Tasmanian governments and the entrepreneurial efforts of the shipbuilding firms. Indeed, reflecting on the early stages of his company's development, Incat's managing director suggested that the collision of the government owned Lake Illawarra with the Tasman Bridge (the event that led Incat to instigate its innovative ferry-building business) was the first and only government assistance that he received (Clifford, 1998). 
A reflection upon the Tasmanian government's policy initiatives during the growth stage of the TLSI's life cycle (1984 - 1999).

During the growth stage of its life cycle, three key state government roles were perceived to positively influence the development of the TLSI. The first was the Tasmanian government's continued effort to enhance the reputation of the regional economy, although the focus of these efforts changed from the domestic maritime market to one of a marketing effort in the international market for fastferry vessels. The second was the Tasmanian government's direct involvement in Incat's sales negotiations with its international customers. The third was the Tasmanian government's policy initiatives that served to maximise the synergistic relationship that existed between Incat and its supplier firms.

The first of the state government policies that positively influenced the development of the TLSI was the continued enhancement of the region's reputation as a centre for maritime excellence, although the policy's focus changed markedly to encompass the international marketplace. Premier Field's press release at the time explained the merit of this strategy:

The government's strategy recognises that to be viable today, companies involved in ship and boat building needed to have a national and international perspective, and develop their operations accordingly. We have been building boats in Tasmania in a regular and conventional way since 1814. As we seek to establish a solid economic base for the $21^{\text {st }}$ Century, nothing is more logical than to expand our marine industry (Field, 1989:2).

This change in focus was driven by the continued success of Incat's innovative product line in the domestic ferry transportation market. Through the use of government sponsored trade missions and the associated negotiation activities, the Tasmanian government used the success of Incat to illustrate the region's maritime competency to international buyers of these products, in turn facilitating an increase in the international demand conditions for Incat's 
production. The Tasmanian government also applied pressure on the remainder of the TLSI firms, and indeed the region's maritime industry as a whole, to similarly increase the quality of their production in line with the growing international reputation of the region. Premier Groom explained the rationale for this policy choice:

Obviously we saw a need to encourage any Tasmanian industry where we had some special advantage. I think we are a maritime state - being an island state, it is particularly relevant to Tasmania and we saw this as something that had potential. We sought to ensure that it wasn't just Incat that drove the industry's success, we needed ot ensure that the set of firms here were able to produce the sort of goods and services that the state had become renowned for (Ray Groom. Personal Interview, 2002).

The Tasmanian government helped the region's shipbuilding and maritime manufacturing firms to achieve high quality production by maintaining its existing lobbying efforts for additional infrastructural funding for the industry. As Premier Rundle stated on the matter of federal government lobbying:

We certainly put in a lot of effort on that using our Federal members and Federal Liberal members as well, there were direct representations made to Canberra by the State Government and also by our Federal Senators. But, they were all on the job, there was no doubt about that, because obviously it was a very important industry, employing probably about 1,000 at that stage (Tony Rundle. Personal Interview, 2002).

Specifically, the Tasmanian government undertook political action to secure additional funding for the educational and research requirements of the industry. As with its direct support for Incat's needs, however, the Tasmanian government only lobbied for additional federal government funding after its need was recognised by the private sector, and where the private sector firms could demonstrate that these needs were necessary for their future growth. The Tasmanian government's reputation enhancement strategy served to increase the demand conditions enjoyed by the state's shipbuilding industry, and in particular, for the output of the regional industry's innovative firm. It also served to apply a 
degree of pressure upon the innovative firm's suppliers to similarly improve their production output in line with the growing prestige of the region.

The second role undertaken by the Tasmanian government was that of direct support during Incat's sales negotiations with their potential international customers. This was directed by the incumbent state Premier at the time, through his department of economic development, most notably in the form of funding for international customer visits to Incat's factory, but also by having the Premier accompany the potential customer during their visit. On the issue of providing this form of support, the Premier commented:

... when [Incat] was involved with the U.K. bloke, I went out for a meal with
him, to give him some comfort, so Incat's Managing Director could show he
had real government support and that everything was on the level. These
efforts were both moral and actual support from us-which is quite important
actually, so that other people know that the government backs them in their
industry. So, if there were visitors that Bob wanted to show, "Yes, the
government is supporting me." We did as much as probably any state
government could rationally do (Michael Field. Personal Interview, 2002).

As a result of the state government's policy initiative to become involved in Incat's sales negotiation process, it provided a level of prestige, moral support and sales expertise that was otherwise beyond the ability of the innovative firm to provide. Indirectly, this policy also served to highlight the supplier firms within the TLSI, as their inputs into Incat's final product were also supported by the state government's involvement in the sale. As Premier Gray stated:

Well, obviously there were down-stream benefits from the catamaran sale itself- even to the creation of the lifeboat technology. We always had Incat's ship as the main product we wanted to help promote, after all the dollars and employment were so important to the state. But we also highlighted the ship's bits and pieces, like the lifeboats and the internal finishes; they were all top quality and deserved mentioning (Robin Gray. Personal Interview, 2002).

By endorsing Incat as the industry’s innovative leader, the government's policy also served to align the TLSI firms' goals by pressuring all of the individual firms to innovate their products in line with the requirements of the innovative 
firm. In terms of advancing the demand conditions enjoyed by the regional industry, the state government's involvement served to enhance the legitimacy of Incat's innovative product to potential international customers. Premier Groom said of this policy initiative that:

\begin{abstract}
We obviously recognised Incat as a major business in the state with huge potential and we did understand that there would be other businesses that would be part of that success and would develop alongside Incat. I just felt that if you could keep this business on the right path and do what we could to back it then there would be other benefits for the peripheral businesses, and indeed the state as a whole (Ray Groom. Personal Interview, 2002).
\end{abstract}

The third key role undertaken by the Tasmanian government was to undertake measures to deliberately maximise the synergistic relationship that existed between Incat and its supplier firms. Inherent to Porter's ICT is the notion that within a network of firms, some forms of scale or scope economies exist through which the industry develops an internationally competitive advantage. Through its development of marine parks and industrial councils (in which firms complementary to Incat's operations can more easily interact) the Tasmanian government deliberately enabled the realisation of the synergies of both scale and scope inherent to the region's natural industry. As noted by Premier Rundle:

I think it was partly due to Incat's expertise and international recognition and partly because of the expertise that we had developing in training of skilled people and also the growing number of companies who were out there doing internationally competitive and technically innovative products and services. Colbeck \& Gunton, they are a company that sells overseas; Richardson \& Devine, they have been on the international market now for a quarter of a century or more. So, it was a logical bringing together of all of the expertise and skills that had been created over a period of probably 20 years - and they had reached a sort of critical mass, at a point where you really did have something to offer because they were companies that you could be confident in, had the expertise and there was a diverse range of maritime products and expertise that gave you a very marketable package (Tony Rundle. Personal Interview, 2002).

The third state government role served to advance the relevant infrastructure by harnessing the synergistic relationship enjoyed by the TLSI firms in residence at the newly established Prince of Wales Bay marine park. With the TLSI firms able to operate in close geographic proximity, the individual firms were better 
able to communicate and coordinate their interrelated production and training activities, as well as allowing them to access the advanced and specialised (and expensive) infrastructure developed for the marine park.

The growth stage of the TLSI's life cycle was characterised by continued efforts by consecutive Tasmanian government to capitalise on the state's growing reputation as a world centre for innovative shipbuilding and maritime production. During the early-growth stage, the Tasmanian government's policy initiatives were focused on Incat as the firm that was driving the innovations within the industry, creating valuable employment, and generating real economic growth for the state. As an indirect result of the Tasmanian government's support for Incat in the early-growth stage, there was pressure placed upon Incat's supplier firms to similarly innovate their products, so that they remained a preferred supplier to Incat. The pressure for Incat's supplier firms resulted in the individual firms receiving both solicited and unsolicited orders from their own international buyers of related products, such as fireproofing equipment, specialised ship fittings, and personal safety devises.

As with the introductory stage of the TLSI's life cycle, the innovative drive within the industry remained solely with the private sector firms. The Tasmanian government remained largely responsible for the development of the required infrastructure to accommodate the industry's growth, and improve its reputation as an innovative centre of global shipbuilding. Similarly, the Tasmanian government's policy initiatives and facilitative infrastructure provision appears only to be provided for after the industry had recognised its necessity to support 
future growth, and was able to demonstrate this formally to the Tasmanian government.

A reflection upon the Tasmanian government's policy initiatives during the maturity stage of the TLSI's life cycle (1999 -).

During the maturity stage of its life cycle, three key state government roles were perceived to positively influence the development of the TLSI. The first key role was the continued enhancement of the regional economy's reputation as a world centre for maritime manufacturing excellence, although the focus of its efforts changed from the singular promotion of Incat's success to incorporate the production of the entire set of industry members, be they involved in Incat's innovative shipbuilding program or otherwise. The second role was to formalise the relationships that existed within the regional shipbuilding and marine manufacturing industries. The third role was the Tasmanian government's deliberate strategy to dilute Incat's importance and impact upon the regional economy.

The first key state government role was its continued enhancement of the regional economy's reputation as a world centre for maritime manufacturing excellence. During the maturity stage however, the focus of the Tasmanian government's reputation strategy in the world shipping vessel market changed from the singular promotion of Incat's success to incorporate the output of the state's entire industry. The following government press release summarises the strategy:

Tasmania is to be marketed as a "one stop shop" for international customers requiring shipbuilding services...the aim of the strategy is to jointly market members' products and services to show the world that Tasmania has the innovative services and products for manufacturing their ships (Napier, 1998:1). 
The Tasmanian state government was able to undertake this integrated marketing strategy given the success that the TLSI firms had enjoyed both individually, and as a network, during the growth phase. For example, by the end of the growth stage of the TLSI's development, each of the supplier firms had secured their own export sales independent of those associated with their alliance with Incat. The functional strategies incorporated by the Tasmanian government included trade missions, direct involvement in the international sales negotiations process, and the provision of integrated marketing assistance to the industry. The marketing assistance provided to the industry was specifically targeted at generating a consistent message for all of Tasmanian firms in the international marketplace.

The second key role was to formalise the relationship between the region's entire set of shipbuilders and maritime manufacturers and the state government. After the Prince of Wales Bay maritime park was established by the Tasmanian government, the private sector firms, along with the Aluminium Welding School, formed the Tasmanian Maritime Network (TMN) within which the TLSI could better develop its communications and lobbying efforts. After the Bacon Labor government's industry audit program of 1998 was completed, the TMN was restructured to form an Industry Council that represented approximately 85 percent of the region's shipbuilding and marine manufacturing firms. The head of the maritime industry council said of the strategy that:

\footnotetext{
The Tasmanian government decided that it would be a good idea to form industry councils - Manufacturing Industry Councils, and a few others. What they found there, through surveys and everything else, it was difficult to bring people together and gain commitment. Now, what we had already, in a way, was one of these councils. It had already formed by our own efforts anyway, so we were able to encourage the rest of industry to join in the council as a group (Terry Hall. Personal Interview, 2002).
} 
The Tasmanian state government provided a secretariat for the council, and a representative for the government to attend the industry council meetings. The industry council meetings sought to provide the region's shipbuilding industry with a direct communications channel between the entire set of firms that accepted the invitation to join, and between the state government and the industry as a whole. The Tasmanian government representative to the maritime industry council stated that:

Our role in the industry council is to provide the secretariat. We don't run the industry council, the industry councils they run themselves, we provide secretarial services, that is, they produce minutes of meetings, distribute the minutes, they produce agenda, mail that out and we do position papers, the industry council tells us to go away and get some information, we do that. For example, they may want to know a bit more about Workplace Health and Safety, so we [the Department of State Development] line a team of speakers from the Workplace Standards Authority who can give, we get an inspector actually talking about, how does it work on the ground, the head of the agency who gives a half hour on agency policy and so on and how they see it (John Keller. Personal Interview, 2002).

The industry council arrangement also helped to ensure that that the set of firms within the industry could better incorporate the success factors of the TLSI into their operations, and therefore become involved in the process of further developing the regional industry’s 'firm strategy structure and rivalry' to comply with world-best standards.

The third key role was the Tasmanian government's strategy to dilute Incat's importance and impact within the regional economy. The policy was implemented through the attraction of additional innovative shipbuilding firms to the region (producing vessels unlike those of Incat) in the hope that the TLSI's supplier firms would have alternate sources of sales opportunities incremental to that of Incat. Premier Bacon indicated the rationale for this policy direction when he stated that: 
One of the big problems identified with the industry at that stage was that it was too reliant on Incat and that having one major company does not a healthy [industry] make! You've got everybody relying on this one company ... we saw that as a weakness of the industry. So, we assisted ... to establish North West Bay Ships, we have given them considerable assistance over the four years, and now it is prospering and growing rapidly and winning new orders (Jim Bacon. Personal Interview, 2002).

The Tasmanian government was able to attract additional innovative firms through marketing the region's advanced infrastructure, support that was initially provided solely for the benefit of Incat. Where needed, the Tasmanian government also provided the option to undertake an equity arrangement with the new firms, an arrangement that involved funding of the new firms' relocation and start-up costs, but did not involve the state government intervening in the innovative process of the firm. Premier Bacon illustrated this policy choice:

So, we assisted ... to establish North West Bay Ships at the Margate Park, we have given them considerable assistance over the four years, in terms of finding them land, purchasing equity, and removing barriers such as zoning issues etcetera. North West are a valuable addition to the [industry], as they are in a different part of the market than Incat, and therefore not taking business away from Incat, but generating new business for the state (Jim Bacon. Personal Interview, 2002).

This policy initiative had a direct impact on the demand conditions enjoyed by the TLSI by effectively driving incremental demand from the international marketplace for region's maritime production. In addition, it allowed the TLSI's supplier firms to develop exponentially greater linkages within the industry, and more importantly, with firms of similar importance as the original firm in terms of their innovative ability and supply requirements.

The maturity stage of the TLSI's life cycle was highlighted by the Tasmanian government's efforts to further enhance the synergistic characteristics of the TLSI, and to extend them to the wider community of marine manufacturers. Interestingly, the Tasmanian government undertook significant and deliberate measures to ensure that the TLSI diversified away from its traditional reliance on 
the demand generated by Incat. In terms of reducing the TLSI's reliance on Incat, the Tasmanian government undertook deliberate measures to dilute the firm's importance as a generator of sales and 'domestic demand' for the remained of the TLSI's production. For the first time, the Tasmanian government undertook an equity arrangement with a similarly innovative firm such that the TLSI's firms would have an increasingly diverse source of internal demand for their production, and perhaps more importantly, their ability to innovative.

\section{Implications.}

The implications for the role of state government in the effective development of a regional economy's industrial policy are four-fold. The first implication surrounds the state government's initial response to the potential formation of an internationally competitive industry. It is interesting that the Tasmanian government maintained an 'arm's length' relationship during the industry's formative stages, allowing the individual firms to determine the pace and trajectory of their innovations. In the TLSI case study, the research indicates that the state government's eventual support for the emergent entrepreneurial activity must be commensurate with its relevance to the region's competitive (or 'natural') advantages and the likelihood of their commercial success in export markets. The reverse holds that state government need to be aware that supporting entrepreneurial activity that does not closely align with the region's competitive advantages as they may be more likely to relocate their activity as more cost effective opportunities arise. Premier Bacon echoes this conclusion:

We have had some examples, back in the '80s, ...they called it "strategy" for God sake, it attracted a number of growth businesses for a while, ... and now most of them have moved to Fiji and elsewhere. It was totally unsustainable because the minute another government grants a greater subsidy, they packed up and left 
because there was no reason for them to be here other than the fact that the government had offered them so much money they would have been mad not to. It was totally unsustainable (Jim Bacon. Personal Interview, 2002).

The second implication is that the role of the government in a regional Australian economy is necessarily variable over the life cycle of the industry, and as a result must have the capability to identify and monitor the set of 'competitive industries' that exist within the region, and their stage of development. It is also important for the government to avoid the adoption of a 'one size fits all' policy regime for its set of industries, as each will have its own requirements given their own particular stage of development. Central to this point is the need for government to be able to recognise the existing and potential synergies that exist within an industry, and therefore be better able to aid the optimisation of this idiosyncratic relationship.

The third implication of this research is that the regional government must provide the required infrastructural needs of the developing industry, however, the manner of its provision is clearly demonstrated by the Tasmanian government in this case. Firstly, the needs of the industry were never pre-empted by the government. Instead, the government awaited a claim from the private sector firms, usually in the form of a business proposal, with demonstrable evidence that without its provision growth and employment within the industry would decline.

The fourth implication is the need for the government to actively dilute the importance of the original innovative firm to the regional economy as the sophistication of its supplier firms similarly advances. It appears necessary to safeguard the innovative firm's suppliers (and indeed the region's entire set of 
industry members) against reliance upon one major entity for their sales growth. Possible methods to achieve this end include the introduction of new firms to the region such that they can benefit from the advanced infrastructure that exist there (creating a set of innovative firms for the supplier firms to interact with), and to apply a positive influence upon these firms to take steps in securing their own discrete export sales.

\section{Conclusion.}

This research contributes a fine-grained reflection of the Tasmanian government's policy initiatives by those that implemented them. The success of the Tasmanian government in building the TLSI suggests that governments should attempt to encourage activities that fit a region's social and economic strengths even when, as in the Tasmanian case, these strengths are subtle. The need to vary the type and strength of government assistance as the industry developed was also emphasised (for example by providing training only after needs had become apparent and could be specifically targeted). Finally, the government was able to change the focus of assistance over time, broadening it to include new industry members as they emerged. Overall, the TLSI presents an object lesson in the advantages of careful government assistance that avoided the perils of taking actions that distorted competition in the nascent industry. 


\section{REFERENCES.}

Australian Manufacturing Council. 1994. The wealth of ideas: How linkages sustain innovation and growth. Melbourne: Australian Manufacturing Council.

Bureau of Industry Economics. 1991. Networks: A third form of organisation. Canberra: Australian Government Printing Service.

Boddy, M. 2000. Technology, innovation, and regional economic development in the state of Victoria. Government \& Policy. 18(3): 301-319.

Brown, R. 2000. Clusters, innovation and investment: Building global supply chains in the new economy. Canberra. Australian Project Developments Pty Ltd.

Burgess, R. G. 1982. Field research: A sourcebook and field manual. London: Routledge.

Clandinin, D. J., \& Connelly, F. M. 1994. Personal experience methods. In N. K. Denzin \& Y. S. Lincoln (Eds.), Handbook of Qualitative Research. California: Sage Publications.

Clifford, R. 1998. Incat - The first 40 years. Victoria: Baird Publications.

Davies, T. 2001. Enhancing competitiveness in the manufacturing sector: Key opportunities provided by inter-firm clustering. Competitiveness Review. 11(2): 4-16.

Digiovanna, S. 1996. Industrial districts and regional economic development: A regulation approach. Regional Studies. 30(4): 373-386.

Edwards, M. 2002. Public sector governance - Future issues for Australia. Australian Journal of Public Administration. 61(2).

Ellis, P. \& Pecotich, A. 2002. Macro-marketing and international trade: Comparative advantage versus cosmopolitan considerations. Journal of Macromarketing. 22(1): 32-56.

Everett, S. 2002. Deregulation, competitive pressures and the emergence of intermodalism. Australian Journal of Public Administration. 61(3).

Feser, E.J. \& Bergman, E.M. 2000. National industry cluster templates: A framework for applied regional cluster analysis. Regional Studies. 34(1): 1-25.

Fontana, A., \& Frey, J. H. 1994. Interviewing: The art of science. In N. K. Denzin \& Y. S. Lincoln (Eds.), Handbook of qualitative research. California: Sage Publication.

Goldfinch, S. 1999. Remaking Australia’s economic policy: Economic policy decision-makers during the Hawke and Keating Labor governments. Australian Journal of Public Administration. 58(2): 3-20. 
Gordon, I.R. \& McCann, P. 2000. Industrial clusters: Complexes, agglomeration and/or social networks? Urban Studies. 37(3): 513-540.

Industry Audit. 1998. Marine manufacturing. Tasmanian State Government Report.

Ivarsson, I. 1999. Competitive industry clusters and inward investments: The case of Sweden. Regional Studies. 33(1): 37-55.

James, D. 2002. How to kick global goals. Business Review Weekly. 24(12).

Keating, P. 1994. Working nation: Policies and programs. Canberra: Australian Government Printing Service.

Kelle, U. 1995 Computer-aided qualitative data analysis: Theory, methods, and practice. London: Sage Publications.

Kelty, B. 1993. Developing Australia: A regional perspective: A report to the Federal Government by the Taskforce on Regional Development. Canberra: National Capital Printing.

Klepper, S. 1996. Entry, exit, growth, and innovation over the product life cycle. American Economic Review. 86(4): 562-583.

Martin, J.F. 2000. Policy consulting and public policy. Australian Journal of Public Administration. 59(1).

McKinsey \& Company. 1994. Lead local compete global: Unlocking the growth potential of Australia's regions. Sydney: McKinsey \& Company.

Napier, S. 1998. Launch of the Tasmanian Maritime Network. State Government Press Release. April 7.

OECD. 1998. Boosting innovation: The cluster approach. OECD Proceedings. Paris.

Peters, E. \& Hood, N. 2000. Implementing the cluster approach. International Studies of Management and Organisation. 30(2): 68-89.

Porter, M.E. 1990. The competitive advantage of nations. New York. Free Press.

Rajneesh, N. 1993. Technology, international business and Porter's "diamond": Synthesizing a dynamic competitive development model. Management International Review.

Richards, T. \& Richards, L. 1995. Using computers in qualitative research. In Denzin, N. \& Lincoln, Y. (editors) Handbook of qualitative research. California: Sage Publishers.

Rugman, A.M. 1991. Diamond in the rough. Business Quarterly. 55(3): 61-64. 
Samuel, A.G. 1982. Phonetic prototypes. Perception \& Psychophysics. 31: 307314.

Staber, U.H., Schaefer, N.V. \& Sharma, B. 1996. Business networks: Prospects for regional development. New York: Walter de Gruyter Publishing.

Trinca, H. 2002. Absolute Porter. Boss - The Australian Financial Review. September Edition.

Weitzman \& Miles, M. 1995. Computer Programs for Qualitative Data Analysis. California: Sage.

Wickham, M.D. \& Hanson, D.J. 2002. Industrial clustering in regional Australia: The role of chance, entrepreneurs and government in the Tasmanian light ships industry. Conference proceedings of the Australia and New Zealand Academy of Management Conference. Victoria, Australia.

Yettin, P. Craig, J. Davis, J. \& Hilmer, F. 1992. Are diamonds a country’s best friend? A critique of Porter's theory of national competitive advantage as applied to Canada, New Zealand and Australia. Australian Journal of Management. 17(1): 89-119. 